to Prof. B. L. Goodlet; Extra Premiums to E. T. Norris, D. J. Bolton, A. H. Davis, O. W. Humphreys, C. E. Fairburn, W. Maurice, J. N. Waite; Wireless Section Premiums to T. C. Macnamara and D. C. Birkinshaw ; J. Bell, J. W. Davies and B. S. Gossling ; A. J. Gill and Dr. S. Whitehead; Meter and Instrument Section Premiums to K. J. R. Wilkinson, T. A. Ledward, C. W. Hughes; Transmission Section Premiums to Dr. J. L. Miller and Dr. J. M. Thomson (Sebastian de Ferranti Premium), Dr. S. Whitehead and Mr. E. E. Hutchings.

\section{Centralized Control of Public Lighting}

IN a paper read to the Institution of Electrical Engineers on May 11 by H. Purslove Barker, a full account is given of the new methods of the centralized control of public lighting and off-peak loads, by superimposed ripples. Although clock-switches have to-day reached a high pitch of mechanical perfection, they are only suitable for services where the switching routine is prearranged and invariable. There are very few applications of this kind of switching where the time of the day is the only element which should regulate the operation of a switch. For example, in street lighting the correct time to switch on and off may be determined by the incidence of fog, war or other emergency. By the aid of a central transmitter it is now possible to transmit signals by ripples of current in the distributing and feeding mains, so that one signal acting on a relay turns street lights on, another controls off-peak loads and so on. The system can operate, from a central position, an unlimited number of inexpensive relays. It appears probable that in many areas very restricted lighting will be permitted during war-time, provided that it can be instantaneously extinguished. A centralized ripple control system is now used in Paris for operating warning syrens over a large area. The same ripple that is used to start warning syrens can also be employed to call air-raid wardens in their homes by the aid of a portable relay comprising a bell which can be plugged into any socket in the network. This system of control may prove useful for many purposes in the future.

\section{Recommendations for Seed Potatoes}

Ротато growers when considering the purchase of seed for next year's planting should obtain the leaflet on seed potatoes which the National Institute of Agricultural Botany, Cambridge, issues free of charge. Despite the encouragement given to potato breeding by the Ministry of Agriculture, and Scottish and Irish Departments of Agriculture for many years, more than 90 per cent of the potato acreage in Great Britain is still planted with varieties which have been on the market for more than twenty years. In most cases, newer varieties could be introduced with considerable benefit, and it is suggested that growers who are naturally reluctant to discard varieties with which they are familiar should at least try small quantities of the newer kinds so that they can test for themselves the value of the recommendations made. In the first-early class, Arran Pilot and Doon Early are suggested, while Gladstone,
Redskin and Arran Signet are the recommendations for second-early or main crop potatoes. For late main crop, Dunbar Standard and Arran Cairn both produce white kidney tubers of excellent quality. A number of the older varieties are susceptible to wart disease and possess such faults as poor shape, indifferent cooking quality and proneness to second growth, but these new varieties are immune from wart disease and are only recommended after careful trial. The certificates issued by the Ministry of Agriculture and Scottish and Irish Departments of Agriculture for growing crops of potatoes, are a reliable guide to the standard of health of the purchased seed, and growers should become familiar with the different grades, that they may understand the nature of the guarantee supplied.

\section{Commonwealth Fund Fellowships Awards}

THE Committee of Award of the Commonwealth Fund fellowships has made the following appointments, among others, to fellowships tenable by British graduates in American universities for the two years beginning September 1938. These fellowships are offered by the Commonwealth Fund of New York, of which Mr. Edward S. Harkness is president : Dr. G. H. Benham, University College, London, to the University of Wisconsin, in biochemistry; Dr. Bernard Cannon, University of Liverpool, to Princeton University in mathematics; A. G. Cowan, University of Glasgow, to Brookings Institution, Washington, in economics; M. W. H. Davies, University College of North Wales, Bangor, to the Massachusetts Institute of Technology, in engineering ; K. J. Laidler, Trinity College, Oxford, to Princeton University, in chemistry; E. H. Lee, Gonville and Caius College, Cambridge, to Stanford University, in engineering; M. W. Lister, Oriel College, Oxford, to Harvard University, in chemistry ; J. M. Meek, University of Liverpool, to the University of California, in engineering ; H. B. Parry, Queens' College, Cambridge, University of Edinburgh, and Royal Veterinary College, London, to the University of Wisconsin, in veterinary science; E. R. Roberts, Imperial College of Science and Technology, London, to the University of Minnesota, in agriculture; H. B. Whittington, University of Birmingham, to Yale University, in geology ; P. V. Youle, University of Sheffield, to the University of California, in physical chemistry.

THE following have been appointed to fellowships tenable by candidates from the British Dominions : A. M. Acock, University of Cape Town, and Brasenose College, Oxford, to the University of California, in botany; J. S. de Wet, University of Cape Town, Balliol College, Oxford, and St. John's College, Cambridge, to the Institute for Advanced Study, Princeton, in mathematics. The following have been appointed to fellowships tenable by candidates holding appointments in Government service overseas : J. G. Crawford, University of Sydney, of the Rural Bank of New South Wales, Government of New South Wales, to Brookings Institution and Government agencies, Washington, D.C., in economies ; 